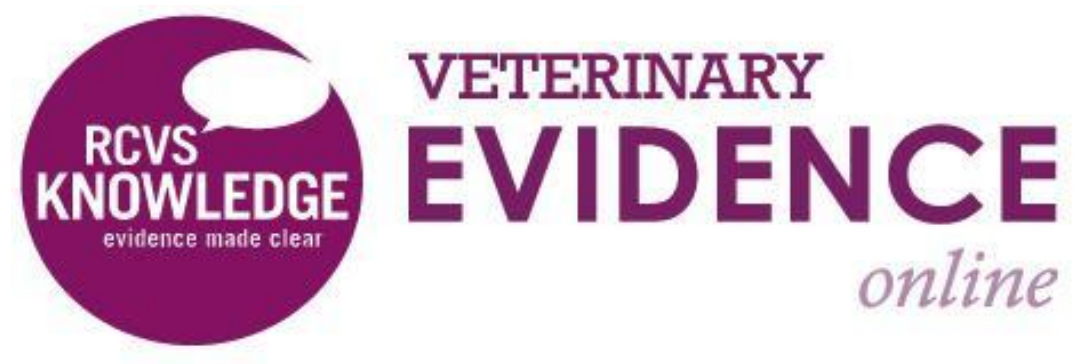

\title{
In Small Animal Surgery Are Alcoholic Hand Rubs Superior to Scrubbing Brushes and Antimicrobial Soap at Reducing Bacterial Counts?
}

\section{A Knowledge Summary by}

Alison Mann BSc (hons), Dip HE CVN, Dip AVN (small animal), RVN ${ }^{1^{*}}$

\footnotetext{
${ }^{1}$ University of Bristol, Senate House, Tyndall Ave, Bristol BS8 1TH

* Corresponding Author (alison.mann@bristol.ac.uk)
}

ISSN: 2396-9776

Published: 2016

in: Vol 1, Issue 4

DOI: http://dx.doi.org/10.18849/ve.v1i4.51

Reviewed by: Victoria Arbona (DVM, MS)

Louise Buckley (BSc Hons, BA Hons, PG Cert

(TLHEP), PGDip, PhD, RVN) 


\section{KNOWLEDGE SUMMARY}

\section{Clinical bottom line}

The current literature suggests that the use of alcohol hand rubs provide similar, if not better, reductions in bacteria colony forming units, both immediately after hand antisepsis and in the immediate postoperative period.

\section{Question}

In small animal surgery are alcoholic hand rubs superior to scrubbing brushes and antimicrobial soap at reducing bacterial counts?

\section{The evidence}

The majority of the literature found was author narrative or looking at the current attitudes and habits that veterinary surgeons have regarding surgical hand preparation. Two relevant papers were found comparing alcohol hand rubs (AHRs) to traditional methods of hand preparation. They differed slightly in that the first paper did not use an abrasive brush in any of the regimes; it only looked at alcohol in different formulations against antimicrobial soap. The second paper did look at the traditional hand scrub with a brush and antimicrobial soap as one of the comparisons.

Many human studies were found, with a number of them having relevance in all areas of the PICO question apart from the population, so these were excluded.

\section{Summary of the evidence}

\begin{tabular}{|c|c|}
\hline Chou (2016) & \\
\hline Population: & $3^{\text {rd }}$ year veterinary students \\
\hline Sample size: & 45 \\
\hline Intervention details: & $\begin{array}{l}\text { The participants were randomly assigned to carry out } 4 \text { of the } 12 \\
\text { possible combinations: } \\
\text { - Non-abrasive hand scrub with } 4 \% \text { Chlorhexidine gluconate } \\
\text { (CHG) antimicrobial soap } \\
\text { - AHR with } 30 \% 1 \text {-propanol and } 45 \% 2 \text {-propanol } \\
\text { - AHR with } 70 \% 2 \text {-propanol } \\
\text { - AHR with } 61 \% \text { ethanol solution with } 1 \% \text { CHG } \\
\text { - All the above products could have had any one of the below } \\
\text { contact times thus making } 12 \text { possible combinations } 1.5,3 \text { or } \\
5 \text { minutes. Using shuffled cards the participants were } \\
\text { assigned } 4 \text { of the possible } 12 \text { combinations }\end{array}$ \\
\hline Study design: & Prospective randomised controlled \\
\hline Outcome studied: & - To compare the antibacterial efficacy of different surgical \\
\hline
\end{tabular}




\begin{tabular}{|c|c|}
\hline & $\begin{array}{l}\text { hand antisepsis protocols used by veterinary students both } \\
\text { at the recommended and at extended contact times } \\
\text { - Antibacterial efficacy was assessed before surgical hand } \\
\text { preparation, after surgical hand preparation and at the end } \\
\text { of surgery. } \\
\text { - Reductions in bacterial colony forming units and positive } \\
\text { aerobic culture rates were compared using multivariable } \\
\text { analysis or variance and multivariable logistic regression. }\end{array}$ \\
\hline $\begin{array}{l}\text { Main findings: } \\
\text { (relevant to PICO question): }\end{array}$ & $\begin{array}{l}\text { - After hand preparation the AHR with } 61 \% \text { ethanol/1\% CHG } \\
\text { and the } \mathrm{CHG} \text { non abrasive antimicrobial soap scrubs were } \\
\text { more effective at reducing log colony forming units (CFUs) } \\
\text { when used at the manufacturer recommended contact time. } \\
\text { Increasing contact time for any of the products did not have } \\
\text { an effect on bacterial reduction immediately after hand } \\
\text { preparation } \\
\text { - At the end of surgery, the product used, the contact time } \\
\text { and the product/ contact time interaction all had effects on } \\
\text { CFU reductions } \\
\text { - At the end of surgery, the AHR with } 61 \% \text { ethanol/ } 1 \% \text { CHG } \\
\text { and the AHR with } 30 \% 1 \text {-propanol and } 45 \% \text { - propanol had } \\
\text { significantly increased bacterial reductions with increasing } \\
\text { contact time } \\
\text { At the end of surgery, at the manufacturer recommended } \\
\text { contact time the AHR with } 61 \% \text { ethanol/ } 1 \% \text { CHG had } \\
\text { significantly higher CFU reduction compared to the AHR with } \\
70 \% 2 \text {-propanol }\end{array}$ \\
\hline Limitations: & $\begin{array}{l}\text { - Authors and participants not blinded to the products used or } \\
\text { the contact time. } \\
\text { Veterinary students may not be as experienced in the } \\
\text { methods of pre-surgical hand preparation. There were } \\
\text { guidelines, however there was likely to be some variability } \\
\text { between participants. } \\
\text { - There was some variability between surgical times ( } 57-255 \\
\text { mins) which may have affected the final samples taken. } \\
\text { However, in the discussion it is stated that the average } \\
\text { surgery time was relatively short } \\
\text { There was no comparison with an abrasive scrubbing brush; } \\
\text { the scrubbing method used a sponge as opposed to a brush. }\end{array}$ \\
\hline
\end{tabular}

\section{Verwilghen (2011)}

\begin{tabular}{|r|l|}
\hline Population: & Small animal and equine surgeons \\
\hline Sample size: & $\begin{array}{l}\text { 3 equine and } 2 \text { small animal surgeons. A total of } 64 \text { samples were } \\
\text { obtained for AHRs (Sterilium) (50 equine, 14 small animal) and } 30 \\
\text { obtained for antimicrobial soap (CHG) (20 equine, } 10 \text { small animal). }\end{array}$ \\
\hline Intervention details: & A preliminary study was carried out comparing Povidone lodine \\
\hline
\end{tabular}




\begin{tabular}{|c|c|}
\hline & $\begin{array}{l}\text { (PVP), CHG and Sterilium. Following this preliminary study it was } \\
\text { found that the actions of the PVP were not comparable to the others } \\
\text { and so the clinical in use study was carried out only using CHG and } \\
\text { Sterilium. } \\
\text { Sample sizes are discussed above. The CHG was used in a } 5 \text { minute } \\
\text { scrubbing technique and the Sterilium was used according to } \\
\text { manufacturer's instructions at } 1.5 \text { minutes after a } 1 \text { minute's hand } \\
\text { wash with neutral soap. } \\
\text { Fingertips were pressed for } 10 \text { seconds onto a blood agar plate } \\
\text { (separate for each hand) and bacterial growth was quantified by } \\
\text { counting the CFUs grown after } 24 \text { hours of incubation. This was } \\
\text { performed prior to hand antisepsis, immediately after hand } \\
\text { antisepsis and after surgery during which the surgeon was double } \\
\text { gloved (the first pair discarded after draping the patient). Mean } \\
\text { surgery time was } 1.5 \text { hours. }\end{array}$ \\
\hline Study design: & Clinical trial \\
\hline Outcome studied: & To compare AHRs to $\mathrm{CHG}$ in a surgical setting \\
\hline $\begin{array}{l}\text { Main findings: } \\
\text { (relevant to PICO question): }\end{array}$ & $\begin{array}{l}\text { - A preliminary study was carried out comparing PVP, CHG } \\
\text { and Sterilium and found that PVP was not comparable to the } \\
\text { other } 2 \text { products and so this was not taken forward into the } \\
\text { further study. } \\
\text { - } 4 \text { Sterilium samples were excluded due to contamination } \\
\text { during surgery, } 1 \text { was excluded due to an infected wound by } \\
\text { the nail of one of the surgeons creating an extreme growth } \\
\text { of staphylococcus aureus. } \\
\text { - Prior to hand antisepsis samples were significantly different } \\
\text { to after hand antisepsis and after surgery samples for both } \\
\text { products. } \\
\text { - No difference was found in CFUs between after hand } \\
\text { antisepsis and after surgery samples for Sterilium. } \\
\text { The clinical in use trial found that there was a significantly } \\
\text { greater reduction factor for the Sterilium compared to CHG. } \\
\text { The results of this study agreed with previous studies carried } \\
\text { out in this area (Parienti et al } 2002 ; \text { Kampf and Osteomeyer, } \\
\text { 2005; Loffler and Kampf, } 2008 \text { and Tanner et al 2008). }\end{array}$ \\
\hline Limitations: & $\begin{array}{l}\text { Residual activity of CHG is difficult to assess without the use of a } \\
\text { neutralising agent as bacteriostatic concentrations of the CHG will } \\
\text { remain. The decision was made to not use a neutralising agent as it } \\
\text { wasn't used in similar studies. } \\
\text { More than double the amount of samples were gained for the } \\
\text { Sterilium group, although some of these did have to be discarded. }\end{array}$ \\
\hline
\end{tabular}




\section{Appraisal, application and reflection}

Two relevant studies were found for this particular PICO question, which both conclude that alcohol is as effective, if not more, than antimicrobial soap for pre surgical hand preparation when used according to the manufacturer guidelines. The AHRs used in the 2 studies, however, was of different formulations. In the first study (Chou et al, 2016) there were 2 formulations of alcohol used: propanol (of different strengths) and alcohol with $\mathrm{CHG}$, of which the alcohol with CHG was found to be the most effective. In the second study (Verwilghen et al 2011) the only alcohol formulation used was propanol (Sterilium). The PICO question only specifies AHRs rather than particular formulations so both studies are relevant.

Another difference between the studies was that Chou et al (2016) did not use an abrasive method of hand scrubbing as one of the comparisons; their non-abrasive scrub method was with the use of a sponge rather than bristles. As the PICO question in this instance was asking for a comparison between scrubbing brushes and AHRs there are some discrepancies between this and the PICO question, but the decision was made to include it. Verwilghen et al (2011) did use the more traditional surgical scrub with a brush as one of their variables, making it very suited to the PICO question.

On reflection, whether in human or veterinary surgery, the end point of pre-surgical hand antisepsis is the same; to have reduced bacterial colony forming units on the hands. The author therefore feels that a future Knowledge Summary with a slight change to the PICO to include human surgery would still be relevant to veterinary professionals to draw evidence from.

\section{Methodology Section}

\begin{tabular}{|r|l|}
\hline \multicolumn{2}{|l|}{ Search Strategy } \\
\hline $\begin{array}{r}\text { Databases searched and dates } \\
\text { covered: }\end{array}$ & PubMed and CAB Abstracts 1973-2016 week 29 \\
\hline Search terms: & $\begin{array}{l}\text { Small animal or veterinary surgery or companion animal or (cats or } \\
\text { cats or feline or felis or dogs or dog or canis or canine) or small } \\
\text { animal surgery and (chlorhexidine gluconate or povidone iodine or } \\
\text { antimicrobial soap) or scrubbing brush or (hand and scrub*) or } \\
\text { scrub and (alcohol rub or alcoholic rub or ethanol or propanol) or } \\
\text { (hand and rub) or rub* }\end{array}$ \\
\hline Dates searches performed: & $\begin{array}{l}\text { 6/8/2016 CAB abstracts } \\
5 / 10 / 16 \text { Pubmed }\end{array}$ \\
\hline
\end{tabular}

\section{Exclusion / Inclusion Criteria}

Exclusion: Large/farm animal studies, human studies, narrative reviews, any studies on skin preparation of patients as opposed to the surgeon, any studies that are not relevant to the PICO question

Inclusion: Small animal/companion animal studies comparing the 2 hand preparation techniques 


\begin{tabular}{|l|c|c|c|c|c|c|c|}
\hline Search Outcome & $\begin{array}{l}\text { Excludase } \\
\text { Dumber } \\
\text { of } \\
\text { results }\end{array}$ & $\begin{array}{c}\text { Excluded }- \\
\text { Narrative }\end{array}$ & $\begin{array}{c}\text { Excluded - Not } \\
\text { relevant to the } \\
\text { PICO }\end{array}$ & $\begin{array}{c}\text { Excluded } \\
\text { Human } \\
\text { study }\end{array}$ & $\begin{array}{c}\text { Excluded - } \\
\text { Duplicate }\end{array}$ & $\begin{array}{c}\text { Excluded - } \\
\text { Large animal } \\
\text { study }\end{array}$ & $\begin{array}{c}\text { Total } \\
\text { relevant } \\
\text { papers }\end{array}$ \\
\hline $\begin{array}{l}\text { CAB } \\
\text { Direct }\end{array}$ & 19 & 1 & 18 & 0 & 0 & 0 & 1 \\
\hline $\begin{array}{l}\text { NCBI } \\
\text { PubMed }\end{array}$ & 554 & 0 & 542 & 11 & 1 & 1 & 1 \\
\hline
\end{tabular}

\section{CONFLICT OF INTEREST}

The author declares no conflict of interest.

\section{REFERENCES}

1. Chou, P. et al (2016) Antibacterial Efficacy of Several Surgical Hand Preparation Products Used by Veterinary Students. Veterinary Surgery, 45 (4) pp. 515-522 http://dx.doi.org/10.1111/vsu.12473

2. Kampf, G. and Osteomeyer, C. (2005) Efficacy of Two Distinct Ethanol Based Hand Rubs for Surgical Hand Disinfection- a Controlled Trial According to prEN 12791. BMC infectious diseases, Vol 5 (19). http://dx.doi.org/10.1186/1471-2334-5-17

3. Loffler, H. and Kampf, G. (2008) Hand Disinfection: How Irritant Are Alcohols? Journal of hospital infection, 70 (S1) PP. 44-48 http://dx.doi.org/10.1016/S0195-6701(08)60010-9

4. Parienti, J. J. et al (2002) Hand Rubbing with an Aqueous Solution vs Traditional Surgical Hand Scrubbing and 30 Day Surgical Site Infection Rates: A Randomised Equivalence Study. Journal of the American Medical Association, 288 (6) pp. 722-727 http://dx.doi.org/10.1001/iama.288.6.722

5. Tanner, J., Swarbrook, S. and Stuart, J. (2008) Surgical Hand Antisepsis to Reduce Surgical Site Infection. [Cochrane Database Systematic Review] [online]. Available from:

http://onlinelibrary.wiley.com/doi/10.1002/14651858.CD004288.pub2/full DOI http://dx.doi.org/10.1 002/14651858.CD004288.pub2 [Accessed 1 October 2016]

6. Verwilghen, D. R. et al (2011) Surgical Hand Antisepsis in Veterinary Practice: Evaluation of Soap Scrubs and Alcohol Based Rub Techniques. The Veterinary Journal, 190 (3) pp. 372-

377 http://dx.doi.org/10.1016/i.tvjl.2010.12.020 


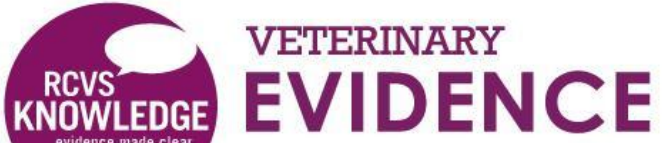 \\ orthe}

\section{Intellectual Property Rights}

Authors of Knowledge Summaries submitted to RCVS Knowledge for publication will retain copyright in their work, but will be required to grant to RCVS Knowledge an exclusive license of the rights of copyright in the materials including but not limited to the right to publish, re-publish, transmit, sell, distribute and otherwise use the materials in all languages and all media throughout the world, and to license or permit others to do so.

Authors will be required to complete a license for publication form, and will in return retain certain rights as detailed on the form.

Veterinary Evidence and EBVM Network are RCVS Knowledge initiatives. For more information please contact us at editor@veterinaryevidence.org.

RCVS Knowledge is the independent charity associated with the Royal College of Veterinary Surgeons (RCVS). Our ambition is to become a global intermediary for evidence based veterinary knowledge by providing access to information that is of immediate value to practicing veterinary professionals and directly contributes to evidence based clinical decision-making.

\section{www.veterinaryevidence.org}

RCVS Knowledge is a registered Charity No. 230886. Registered as a Company limited by guarantee in England and Wales No. 598443.

Registered Office:

Belgravia House

62-64 Horseferry Road

London SW1P 2AF 